\title{
BACTERIAL BIOFILMS WITH EMPHASIS ON COAGULASE-NEGATIVE STAPHYLOCOCCI
}

\section{OLIVEIRA A (1), CUNHA MLRS (1)}

(1) Department of Microbiology and Immunology, Botucatu Biosciences Institute, São Paulo State University, UNESP, Botucatu, São Paulo State, Brazil.

\begin{abstract}
In addition to their capacity to attach to surfaces, various groups of microorganisms also produce an extracellular polymeric substance known as "slime". This slime forms a thin layer around cells known as biofilm. Thus, biofilm structure comprises bacterial cells and an extracellular polymeric substance. It also presents a defined architecture, providing the microorganisms with an excellent protective environment and favoring the exchange of genetic material between cells as well as intercellular communication. The ability to produce biofilm is observed in a large group of bacteria, including coagulase-negative staphylococci (CNS) which are the predominant microorganisms of normal skin flora and have been implicated as the causative agents of hospital infections. Bacteremia caused by these agents is common in immunodepressed persons, in patients with cancer, in adult and neonatal intensive care units (ICU) and in patients using catheters or other prosthetic devices. The pathogenicity of CNS infections is probably related to the production of slime, which adheres preferentially to plastic and smooth surfaces, forming a biofilm that protects against attacks from the immune system and against antibiotic treatment, a fact hindering the eradication of these infections. The main objective of the present review was to describe basic and genetic aspects of biofilm formation and methods for its detection, with emphasis on biofilm creation by CNS and its relationship with diseases caused by these microorganisms which are becoming increasingly more frequent in the hospital environment.
\end{abstract}

KEY WORDS: coagulase-negative staphylococci, biofilm, slime, infection, microbiology.

CONFLICTS OF INTEREST: There is no conflict.

FINANCIAL SOURCE: Fapesp.

CORRESPONDENCE TO:

MARIA DE LOURDES RIBEIRO DE SOUZA DA CUNHA, Departamento de Microbiologia e Imunologia, Instituto de Biociências, UNESP, Caixa Postal 510, Botucatu, SP, 18618-000, Brasil. Fax: +55 143815 3744. Email: cunhamlr@ibb.unesp.br. 


\section{INTRODUCTION}

Biofilms are not simple organism-containing viscous layers; they represent highly organized systems in which bacteria establish functional structured and coordinated communities (27). Some groups of microorganisms are able to adhere to a surface and to develop biofilms. These biofilm-associated cells can be distinguished from suspended planktonic cells by the production of an extracellular polymeric substance (EPS), by the reduced growth rates of the colonies and by the regulation of specific genes. The attachment process is highly complex and regulated by different characteristics of the growth medium, substrate and cell surface. The biofilm structure comprises microbial cells and EPS, has a defined architecture and provides an excellent environment for the exchange of genetic material among cells (29).

Coagulase-negative staphylococci (CNS) have recently been identified as important causes of hospital infections. An important step in the development of catheter- or implant-associated infections caused by CNS is the adhesion and attachment of these bacteria to biomaterial surfaces $(5-7,9,15,18,25,35,39,48,56,68)$.

Among the various mechanisms involved in bacterial adhesion, the production of an extracellular polysaccharide substance called slime plays a relevant role. This substance strengthens in surface adhesion like cement, permitting the agglomeration of bacterial cells into biofilms or multilayers. Once formed, these biofilms render the cells less accessible to the defense system of the organism, thus impairing the action of antibiotics and, in turn, represents basic survival strategies of these microorganisms, a fact that explains why biofilms are considered to be of great importance for public health. Therefore, studies and diagnostic methods identifying virulent bacterial strains, i.e., strains with a capacity for slime production and consequent biofilm formation, are necessary to develop effective strategies for biofilm control and improvement of patient care $(3,5,6,9,13,22,25,27,56,68)$.

Since biofilm-producing CNS are potentially involved in the occurrence of catheterassociated infections, transforming microorganisms from the normal flora to important opportunistic pathogens in immunocompromised patients - such as preterm newborns, neutropenic oncology patients, seniors with severe underlying diseases, hospitalized patients submitted to invasive procedures and those with permanent plastic devices -, the objective of the present review was to provide further data regarding biofilms that may contribute to future studies on this subject. 


\section{A HISTORY OF BIOFILMS}

Donlan and Costerton (30) cite Van Leeuwenhoek, who observed "animalcules" in the plaque of his own teeth using a simple microscope, as the pioneer in the discovery of microbial biofilms. Heukelekian and Heller (42), studying marine microorganisms inside a bottle, observed that bacterial activity and growth were markedly increased in this container due to the incorporation of a surface to which these organisms could adhere. Analyzing seawater, Zobell (69) noticed that the number of bacteria attached to surfaces was higher than in the surrounding medium. However, a detailed study of biofilms only became possible with the advent of the electron microscope, which permits high-resolution photomicroscopy at magnifications hundreds of times higher than those obtained with the light microscope. Jones et al. (46), employing scanning electron microscopy, investigated biofilms in a water treatment plant and, based on cell morphology, demonstrated that biofilms consist of a variety of organisms. In addition, the authors were able to show that the matrix material surrounding and enclosing cells in these biofilms consisted of polysaccharides. Characklis (11) investigated microbial slimes in industrial water systems and showed that they were not only persistent but also resistant to disinfectants like chlorine. However, the theory of biofilm predominance was only promulgated in 1978 by Costerton et al. (19) based on observations of dental plaque and sessile communities in mountain streams. This comparison of organisms in their natural environment and in dental plaque permitted the understanding of the mechanisms whereby these microorganisms adhere to living and nonliving materials and the benefits of this type of ecological niche. According to Donlan (29) and Costerton and Lashen (20), since 1978 studies of biofilms related to public health, industry and ecology have been carried out in parallel. Scanning electron microscopy and standard microbiological culture techniques have been important tools for the characterization of biofilms in the last few decades, during which two main tools have revolutionized the understanding of biofilms: laser scanning microscopy and the investigation of the genes involved in cell adhesion and biofilm formation.

Numerous studies on biofilms published over the most recent decades have contributed to the understanding of numerous infectious diseases associated with biofilm growth. Many infections that occur in hospitalized patients who use medical devices, such as prostheses or catheters, are related to biofilms. Bacteria from normal skin flora of patients or hospital personnel come in contact with objects on 
which biofilms develop, facilitating the entry of these microorganisms into the organism and rendering the infection persistent due to the several advantages encountered by bacterial cells when enclosed in these biofilms (29).

Staphylococcus epidermidis, the most frequently detected CNS species and one of the main inhabitants of normal skin and mucosal flora, has been identified as the major nosocomial pathogen associated with infections due to implanted medical devices as a result of its great biofilm production capacity (55).

Since biofilms play a role in numerous human activities, researchers from various areas have conducted a large number of studies that aimed to prevent infections related to biofilms or to their accumulation in water or industrial equipment where they cause damage and, consequently, great financial losses. In view of the large number of scientific fields involved, an arsenal of techniques is available for the biofilm study, ranging from molecular microbiological methods applied laboratorycultured monospecies biofilms to the use of microsensors for the study of algal carpets (51).

\section{DEFINITION OF BIOFILMS}

According to Donlan and Costerton (30), the definition of biofilms has evolved over the last 25 years. In 1976, Marshall described the biofilm as the envelopment of "very fine extracellular polymeric fibrils" attached to bacteria. Many authors define biofilms as associations of microorganisms and their extracellular products adhering to biotic or abiotic surfaces (27).

\section{IMPORTANCE OF BIOFILMS FOR BACTERIA}

According to Donlan (29), biofilms are a survival strategy used by bacteria in natural and industrial systems and on medical devices such as prostheses and catheters as a protection against chemical antibacterial substances (including natural antibiotics), environmental bacteriophages and phagocytic cells. In bacterial infections associated with biofilm formation, microorganisms are resistant to antibiotic therapy as well as to host defense mechanisms such as antibodies and phagocytes.

\section{BIOFILM STRUCTURE}

Studies on the structure of biofilms have shown that they primarily consist of microbial cells and EPS that accounts for 50 to $90 \%$ of their total organic carbon and 
can be considered their main formation material. Although EPS varies in its physical and chemical properties, it is primarily composed of polysaccharides. Biofilm polysaccharides can be neutral or polyanionic, as in gram-negative bacteria. One important characteristic is the anionic property of EPS conferred by the presence of uronic acids (D-glucuronic, D-galacturonic and mannuronic acids). This property favors the association of bivalent cations, such as calcium and magnesium, that have been shown to bind to the polymers and contribute to the binding strengh in a developed biofilm. Some bacteria like Staphylococcus present a cationic chemical composition of EPS (30). Hussain et al. (43) demonstrated that CNS slime consists of a teichoic acid mixed with small amounts of proteins. EPS can incorporate large amounts of water into its structure due to is hydrogen bonding ability and are therefore highly hydrated.

According to Sutherland (66), the composition and structure of polysaccharides determine their primary configuration, as is the case of many bacterial EPS, which possess backbone structures that contain $1,3-\beta$ or $1,4-\beta$-hexose residues and tend to be more rigid, less malleable and, in certain cases, poorly soluble or insoluble, whereas others are readily soluble in water. In addition, EPS is not uniform but may vary spatially and temporally. Leriche et al. (53), employing the binding specificity of lectins for simple sugars to evaluate the development of bacterial biofilms in different organisms, concluded that different organisms produce variable amounts of EPS and that the quantity of EPS increases with the age of the biofilm. EPS can also associate with metal ions and macromolecules (proteins, DNA, lipids and organic substances). Some culture medium conditions - excessive carbon availability and limited amounts of nitrogen, potassium or phosphate - affect EPS production. Slow bacterial growth also results in an increase of EPS production. Since EPS is a highly hydrated compound, it prevents desiccation in natural biofilms.

Tolker Nielsen and Molin (67) showed that biofilms contain microcolonies of bacterial cells enclosed in an EPS matrix and that these structures are separated by interstitial voids (water channels). The water channels are important for fluid circulation, thus permitting the flow of nutrients, oxygen and microorganisms from one site to another. Even pure culture biofilms such as those found on instrument surfaces or associated with medical devices are heterogenous. According to Stoodley et al. (63), biofilms generally comprise a thin base film that ranges from a monolayer of cells to a film of 
several layers that contain water channels. The structure of biofilms is also influenced by the organisms that comprise the biofilm.

According to James et al. (45), biofilm thickness may be affected by the number of microorganisms that compose it. Pure cultures of Klebsiella pneumoniae or Pseudomonas aeruginosa grown in a laboratory reactor presented thinner biofilms (15 and $30 \mu \mathrm{m}$, respectively), whereas a biofilm containing both species was thicker. Jones et al. (46) suggested that this finding may be due to the fact that one species increases the stability of another. On the basis of the aforementioned studies, we conclude that biofilm architecture is heterogenous in space and time. Donlan (29) reported that biofilm structure and architecture may also be influenced by the interaction of particles of nonmicrobial components from the host or environment. One example is the accumulation of erythrocytes and fibrin during biofilm formation. Another classic example of this interaction is observed on natural heart valves, where microcolonies develop a biofilm - from a matrix of platelets, fibrin and EPS - while the organisms are protected inside the forming fibrin capsule from host leukocytes, causing infective endocarditis.

\section{BIOFILM ECOLOGY}

Biofilms present in natural and industrial water systems or on medical devices provide the ideal environment for the exchange of energy and material among microorganisms, including gene exchange and nutrient circulation. This environment is favorable due to the proximity of cells within microcolonies or between microcolonies. Bacteria in biofilms are subject to predation by protozoans and to competition with other bacteria, although some species are able to coexist harmoniously (28). Murga et al. (58) demonstrated the colonization and consequent predation in heterotrophic biofilms by Hartmannella vermiformis, a free-living protozoan. Predation has also been observed by Acanthamoeba spp. in biofilms of storage cases for contact lens.

James et al. (45) reported that competition also occurs inside biofilms and demonstrated that invasion of a Hyphomicrobium sp. biofilm by Pseudomonas putida resulted in the dominance of the latter, although the numbers of biofilm-associated Hyphomicrobium remained relatively constant. Donlan (29) cited the study of Stewart who investigated biofilms containing $K$. pneumoniae and $P$. aeruginosa and observed that both species are able to coexist in a stable community. 
Several decades ago, it was proposed that bacteria represent interactive organisms that are able to act collectively, facilitating their adaptation to environmental changes. The establishment of a multicellular behavior is necessary for the formation of a biofilm consisting of one or several species, which is reflected in coordinated activities of interaction and communication among various organisms (27) (Figure 1). One of the mechanisms of interbacterial communication that has been proven extremely important for the formation and development of biofilms is "quorum sensing" (27), a system by which bacteria communicate with one another through signaling molecules, called autoinducers, that regulate bacterial behavior according to population density (64).

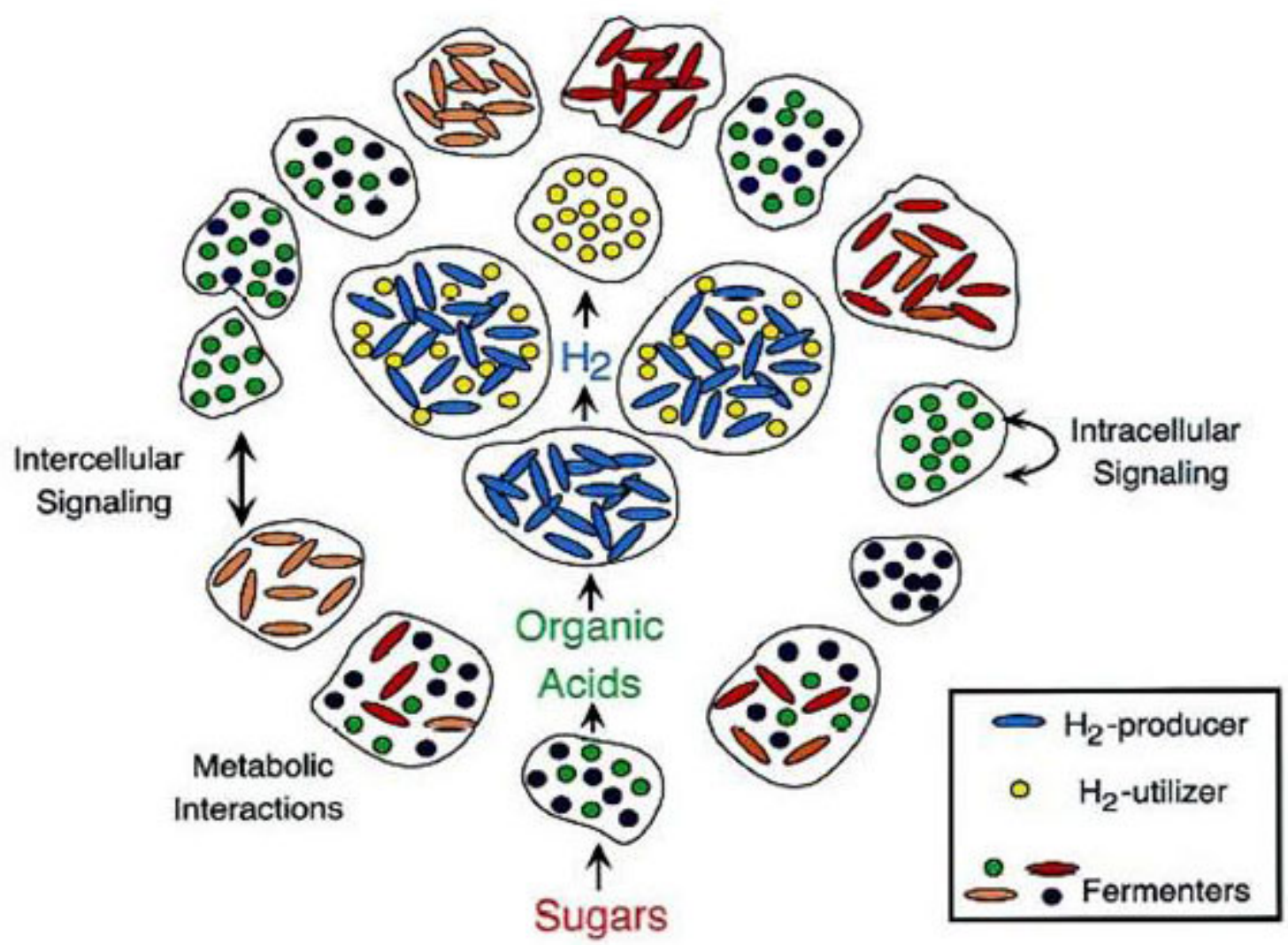

Figure 1. Example of microbial community ecology. The four central microcolonies correspond to organisms that generate and consume hydrogen. The fermenters use sugars and produce organic acids that are used by hydrogen producers. In addition to metabolic interactions, intra- and intercellular communication may be mediated by signaling molecules. Adapted from Davey and O'Toole (27). 


\section{Gene Transfer}

The proximity of cells inside microcolonies or among microcolonies also provides an excellent environment for the exchange of genetic material. The mechanism of conjugation, i.e., the transfer of plasmids between bacteria, occurs at a higher proportion in biofilm bacterial cells than among planktonic cells (29). Ghigo (37) suggested that clinically relevant strains of bacteria containing conjugative plasmids develop biofilms more readly. The author showed that the $F$ conjugative pilus (encoded by the TRA operon of the F plasmid) acts as an adhesion factor in cell-tosurface and cell-to-cell interactions, resulting in a three-dimensional biofilm of Escherichia coli. Many organisms that did not carry plasmids produced only microcolonies, but when these microorganisms received the plasmid from donor bacteria they also started to produce biofilms. In addition to cell-to-cell contact, the biofilm environment provides adherence while plasmids may also encode resistance to multiple antimicrobial agents. This association with the biofilm also provides a selection mechanism and promotes the dissemination of bacterial resistance to antimicrobial agents.

\section{Biofilm Formation Mechanisms, Attachment and Substrate Effects}

The ideal environment for the attachment and growth of microorganisms is a solidliquid interface between a surface and an aqueous medium (e.g. water or blood). Various factors influence the biofilm formation mechanisms such as substrate effects, the types of conditioning film forming on the substrate, characteristics of the medium and properties of the cell surface. As a surprise to the medical community, bacteria preferentially form biofilms on very smooth surfaces. This fact was confirmed in studies investigating the adhesion of laboratory and wild-type bacterial strains to smooth and rough surfaces. The results showed that smooth surfaces are colonized as easily as rough surfaces. Once a biofilm has formed and the exopolysaccharide matrix has been secreted, the resultant structure resembles rubber, i.e., it is viscous and elastic $(12,30)$.

Biofilms formed on rougher surfaces have been shown to possess a low tensile strength and to break easily, whereas biofilms formed on much smoother surfaces are stronger and more resistant to rupture, although the solid surface seems to present many characteristics important to the attachment process $(21,30)$. Characklis (11) showed that the extent of microbial colonization is heightened with 
increasing surface roughness, because shear forces are reduced and the surface area of rougher surfaces is larger. Another factor that exerts a strong influence on the rate and extent of attachment is represented by the physicochemical properties of the surface $(2,21)$.

Vuong and Otto (68) described biofilm formation as follows: in the first stage, bacteria may become attached to the free surface of the polymer; in the second, they become attached to the surface of the protein layer, which will subsequentially cover the polymer. Once attached, bacteria start to multiply and form numerous layers (accumulative phase). The biofilms of $S$. epidermidis do not contain other bacterial species probably because of the action of bacteriocins produced by this species. A capsular polysaccharide molecule, called polysaccharide adhesin, seems to influence attachment to the uncoated surface. After the surface is coated with a protein layer, S. epidermidis interacts with it through different surface molecules. Fibrinogen-binding protein of $S$. epidermidis mediates bacterial adherence to fibrinogen. Bacterial layers are formed by the binding of cells to one another through polysaccharide intercellular adhesin (PIA), a polysaccharide molecule that favors adhesion between cells, and through an extracellular protein called accumulationassociated protein.

The study by Vuong and Otto (68) showed a significant increase in PIA during tricarboxylic acid (TCA) cycle stress. The authors reported abundant PIA production in a nutrient-replete medium even when iron was limited or under conditions of low oxygen availability. However, a stress-inducing stimulus such as the addition of sugar motivated fermentation, with a consequent production of ethanol and an increase in salt concentration, thus elevating the PIA production. This condition of the medium was also found to repress TCA cycle activity and raised the hypothesis that changes in TCA cycle activity affect PIA production. Culturing S. epidermidis with a low concentration of the TCA cycle inhibitor fluorocitrate dramatically increased PIA production without affecting glucose catabolism. These data led the authors to speculate that alterations in the growth medium and/or in the TCA cycle cause changes in the intracellular levels of ATP biosynthesis or even in the redox status of the cell. These changes in bacterial metabolic status may result in the attenuation of PIA production.

PIA is a linear homopolymer of up to $130 \beta-1,6$-linked $\mathrm{N}$-acetylglucosamine residues which consists of two polysaccharide fractions: polysaccharide I (> 80\%) which 
contains 15 to $20 \%$ diacetylated residues and is therefore positively charged, and polysaccharide II $(<20 \%)$ which is structurally related to polysaccharide I but contains a smaller number of non- $\mathrm{N}$-acetylated D-glucosamine residues and phosphate and ester-linked succinate, and is therefore anionic $(4,33,39,57)$.

\section{Genes Controlling Biofilm Formation in Staphylococcus aureus and Staphylococcus epidermidis}

Many saprophytic organisms, including Staphylococcus epidermidis, are part of the normal microflora of mucosa and skin. Whereas $S$. aureus has always been a causative agent of infections in humans, under certain conditions $S$. epidermidis may also cause infections; therefore, it is considered an opportunistic agent. Over the most recent decades, S. epidermidis has emerged together with $\mathrm{S}$. aureus as a frequent etiological agent of infections associated with catheters, prostheses and other medical devices. One of the main mechanisms responsible for the development of severe device-associated infections is the formation of biofilms that facilitate the bacterial adhesion and colonization of these materials. Recent studies have shown that both $S$. aureus and S. epidermidis are able to produce biofilms. According to Arciola et al. (5), the genetic control of slime production has recently begun to be elucidated, first in S. epidermidis and then in S. aureus.

The genes encoding the most important substances and proteins, especially a polysaccharide adhesin, that participate in biofilm formation belong to the ica operon. This operon contains the icaADBC genes and the regulatory icaR gene which is transcribed in the direction opposite to the ica operon. Briefly, the synthesis of the polysaccharide capsule is mediated by the ica operon. When this operon is activated, PIA and poly-succinyl-glucosamine are synthesized and support cell-to-cell contacts by means of a multilayer biofilm. PIA is formed from UDP-N-acetylglucosamine by the enzyme $\mathrm{N}$-acetylglucosamine transferase, which is encoded by the intercellular adhesion (ica) locus, particularly the icaA gene. The expression of icaA alone in isolation induces only low enzymatic activity, but coexpression of ica $A$ and icaD leads to a significant increase in the activity of $\mathrm{N}$-acetylglucosamine transferase, which catalyzes the formation of oligomers with approximately 20 residues. Expression of the icaC gene leads to the synthesis of longer oligomers (130 residues) that react with PIA-specific antisera. The function of the icaB gene has not been established (4, $6,9,16,23,32,35,38,48,56,57,59,60$ ) (Figure 2). 


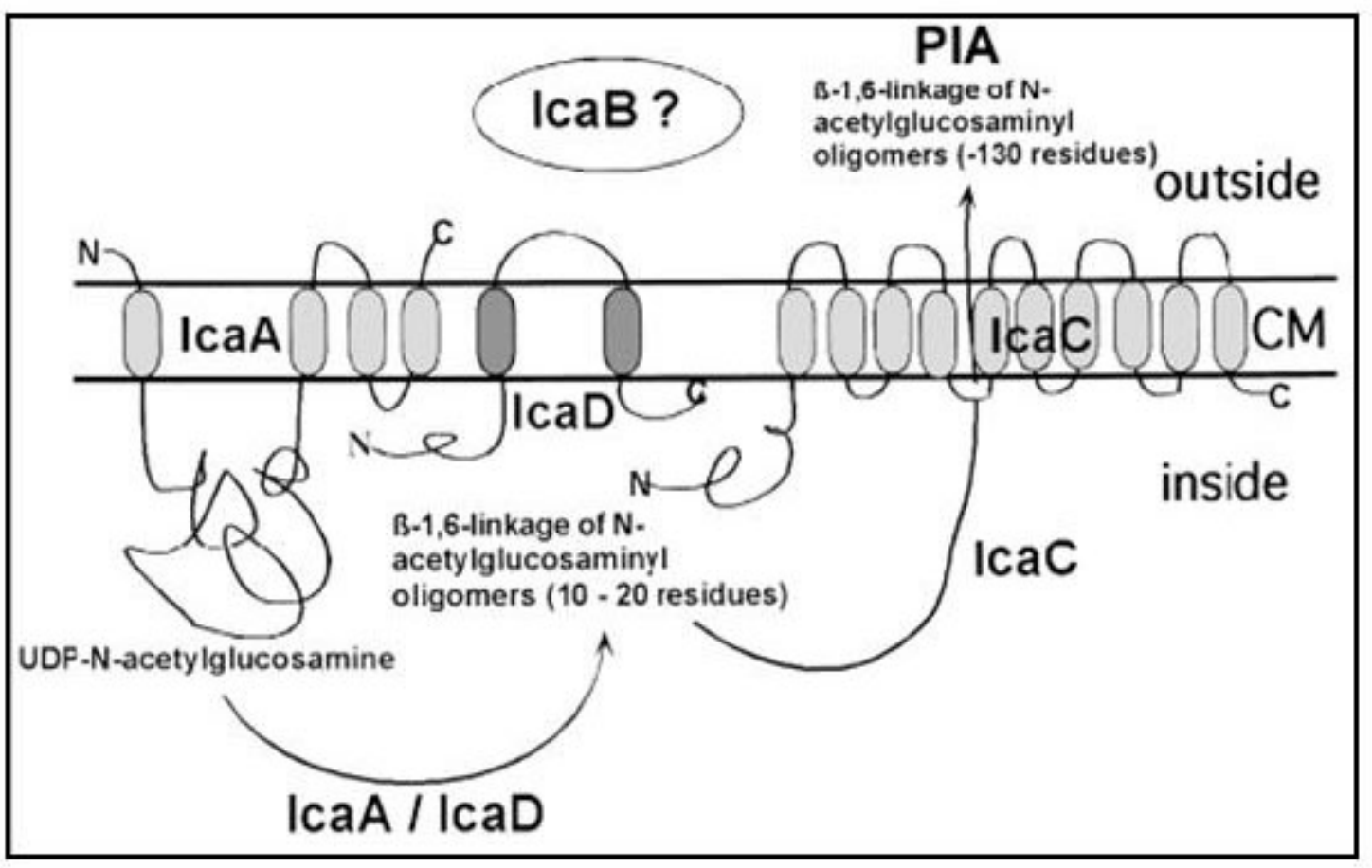

Figure 2. Model of PIA synthesis. IcaA and IcaD synthesize oligomers, derived from UDP-N-acetylglucosamine, consisting of 10 to 20 residues. In the presence of IcaC, longer oligomers containing 130 residues are formed by reacting with two PIAspecific antisera. Due to IcaB's sequence similarity with diacetylases, it may catalyze diacetylation.

CM: cytoplasmic membrane.

Adapted from Heilmann et al. (41), Gerke et al. (36) and O. Schweitzer (unpublished results).

Some studies have suggested that icaR gene product is a transcription repressor that plays an adaptive role in the regulation of the ica operon expression depending on environmental conditions. Some factors such as anaerobic growth, the presence of antibiotics like tetracycline at subinhibitory concentrations, and environmental stress including high osmolarity, may increase the expression of the ica operon. The genes encoding virulence factors in S. epidermidis, as well as the ica operon, seem to be controlled by the global agr and sar regulatory systems, similar to what is observed in S. aureus (5).

Li et al. (54) confirmed that biofilm formation in S. epidermidis depends on PIA, whose biosynthesis is mediated by the ica operon. The authors transferred a plasmid containing the ica operon to three ica-negative bacterial strains. Using rats as experimental models, the authors infected these animals with bacteria harboring the ica operon. These bacteria, then, produced a biofilm and were pathogenic to rats, 
thus confirming the importance of the ica operon for biofilm production and for the pathogenesis of S. epidermidis.

Arciola et al. (4) investigated the role of the icaA and icaD genes in slime production in clinical staphylococcal samples. The coexpression of icaA and icaD was analyzed by the polymerase chain reaction (PCR) in a collection consisting of: 91 Staphylococcus strains (68 S. epidermidis and $23 \mathrm{~S}$. aureus strains) isolated from catheter-associated infections, ten strains obtained from skin and mucosa of healthy volunteers, and two reference strains. The phenotypic slime-forming ability was tested by the Congo red agar method. Among the analyzed isolates, $49 \%$ of $S$. epidermidis strains were from catheters and $61 \%$ of $S$. aureus strains produced slime and were positive for icaA and icaD. None of the saprophytic strains produced slime and all were negative for icaA and icaD. Two S. aureus strains and one $S$. epidermidis strain isolated from catheter tips, were positive for icaA and icaD by PCR, and were slime producers by the Congo red method, in which they exhibited small red dots in the center of black colonies after 48 hours. The presence of these variants could not be attributed to a mutagenic potential of Congo red which, in the Ames test, did not present mutagenicity. PCR showed that these red variants were negative for $i c a A$ and $i c a D$ and were even lacking the icaADBC operon. These data indicate an important role of the ica genes as a virulence factor in intravenous catheter-associated staphylococcal infections. Regarding the genetic factors studied, the authors concluded that the recent advances in genome research will have a crucial influence on future investigations concerning the pathogenesis of Staphylococcus.

\section{Slime Production by Coagulase-negative Staphylococci and Its Association with Infections and Diseases}

Various CNS species including S. epidermidis have become the main causes of nosocomial infections, especially those affecting newborns, immunodepressed individuals and patients hospitalized in the ICU using catheters or other prosthetic devices. These infections can be endogenous or exogenous, arising from the hospital environment or from medical staff hands.

In addition to the conditions of the patient, the pathogenicity of CNS is favored by the ability of these microorganisms to attach to smooth surfaces and to produce large amounts of extracellular substances which form a biofilm that confers protection 
against the defense mechanisms of the host and the action of antibiotics. As an important virulence factor, this biofilm-producing capacity is one of the mechanisms that explains the colonization of medical devices and possible infections with staphylococci $(1,3,7,18,22,35,39,47,50,56,57)$.

Controversial results have been reported by some investigators regarding the association between slime production and clinically significant infections caused by CNS or even concerning differences in the pathogenic potential between slimeproducing and non-producing strains. No evidence is available about the role of host protein receptors expressed by CNS. In this respect, some studies have clearly demonstrated the ability of $S$. epidermidis to adhere to immobilized plasma proteins, whereas others reported that these proteins reduce or block the staphylococcal adhesion. These contrasting results were attributed to a "masking action" of slimecovering protein receptors in in vitro assays (3).

In view of the findings regarding CNS, Alcaraz et al. (1) conducted a study on CNS species identification in terms of slime production and oxacillin susceptibility of strains isolated from nosocomial infections. Most slime-producing CNS strains (environmental and clinical) were resistant to oxacillin. The authors concluded that precise detection and effective control of these microorganisms are necessary in order to prevent their dissemination in hospitals, particularly among immunocompromised patients.

In contrast to $S$. aureus, S. epidermidis is unable to produce large amounts of enzymes and toxins, so that infections caused by the latter are subacute or chronic. S. epidermidis has become an important agent of hospital infections because of its ability to adhere to polymer surfaces and to form a biofilm, the latter being considered its main virulence factor (55).

Cerca et al. (10) demonstrated the importance of biofilm production in the development of infections and diseases which confers resistance against antibiotics, by quantitatively comparing the antibiotic susceptibility of biofilm-producing $S$. epidermidis and S. haemolyticus with the susceptibility of planktonic bacteria. The results showed that biofilm-producing bacteria were resistant to antibiotics which inhibited cell wall synthesis, but were susceptible to inhibitors of RNA and protein synthesis, whereas planktonic cultures were susceptible to both.

Ishak et al. (44), investigating slime production by CNS, reported that the presence of slime seems to adversely influence opsonization and phagocytosis, inhibiting 
polymorphonuclear leukocyte (PMN) chemotaxis, which induces PMN degranulation, inhibiting the oxygen-dependent metabolic activities of PMN which normally occur during phagocytosis, and subsequent intracellular death, influencing the interactions of surface opsonins, which are a prerequisite for the processing of phagocytic.

One of the frequent causes of death in patients treated for hydrocephalus has been ventriculoperitoneal shunt infection. Antimicrobial therapy has been successful in some of these cases, but otherwise removal of the shunt and concomitant appropriate antimicrobial therapy are recommended. Diaz-Mitoma et al. (28) reported that CNS are responsible for 36 to $80 \%$ of these infections. Slime-producing strains were the most common contaminants of the foreign bodies used. In view of speculations by researchers about whether slime production is involved in the pathogenesis of these infections, Diaz-Mitoma et al. (28) determined slime production in CNS isolated from ventriculoperitoneal shunt infections. Eleven cases of infection were caused by slime-producing CNS and eight cases were caused by non-producing strains. The shunt obstruction and abdominal pain were more frequent when infectious cases were due to slime-producing CNS than when they were caused by non-producing CNS. Despite appropriate antimicrobial therapy, the mean duration of fever was longer and failure to eradicate the infectious organisms was more frequent when the infectious cases were due to slime-producing CNS.

Several investigators have indicated exopolysaccharide or slime production as an epidemiological marker of infection in pediatric patients $(31,40)$. Similar studies mainly conducted on adult patients have reported a higher frequency of slimeproducing CNS strains to be involved in the etiology of infections compared to nonproducing strains $(8,14)$. Kotilainen $(50)$, evaluating the importance of slime production as a virulence factor in strains isolated from septicemia patients in two Finish hospitals attended by the same microbiology laboratory, reported conflicting results, suggesting that slime production was certainly an important virulence factor. However, this relationship between slime production and clinically significant infections may not be a universal phenomenon. Probably, virulence factors other than slime production also contribute to the pathogenesis of these microorganisms, with these factors varying in different environments.

Cunha et al. (26) have shown that only a small proportion of strains producing this exopolysaccharide $(22.2 \%)$ is associated with infectious processes in newborns. Other authors also reported lack of evidence that slime is a virulence factor $(13,51)$. 
On the other hand, slime-producing CNS strains have been more frequently isolated from patients with sepsis than from patients without invasive disease, indicating the risk of invasive disease in patients harboring slime-producing CNS (40). Similar results have been observed by Cunha et al. (26) who found a significantly higher frequency of slime-producing S. epidermidis strains in blood cultures $(20.4 \%)$ and foreign bodies $(21.9 \%)$ than in secretions (0\%). Cunha et al. (24) also conducted studies in order to identify CNS species and to determine the influence of slime production during the course of peritonitis in patients submitted to continuous ambulatory peritoneal dialysis (CAPD). Slime production was independently associated with the non-resolution of peritonitis cases caused by CNS during CAPD, with peritonitis caused by non-slime-producing CNS presenting a 27 times higher chance of cure than episodes caused by slime-positive CNS.

Slime production may also vary from species to species. According to Christensen et al. (15), slime production is more frequent in strains of S. capitis, S. epidermidis, S. hominis and S. saprophyticus. Among CNS species isolated in various studies (2426, 33), slime production was observed in S. epidermidis, S. lugdunensis and S. hominis.

Methods for the Detection of Slime Production in Coagulase-negative Staphylococci

Different methods are currently employed to detect biofilms, including visual techniques including scanning electron, transmission electron and epifluorescence contrast microscopy, and non-visual methods such as the measurement of impedance and bioluminescence. Qualitative analyses - like the tube method by Christensen et al. (13) and the Congo red agar method by Freeman et al. (34) - and quantitative assays - such as tissue culture plate (TCP) method by Christensen et al. (15) - have also been described. In addition, molecular methods (PCR) are used to provide direct evidence of the genetic basis of slime production. Electron microscopy has been used since the first study on biofilms for their examination and measurement. This technique requires gradual dehydration of the samples since the water is not compatible with vacuum employed by the electron beam. Graded solvents such as alcohol, acetone and xylene are used for this purpose. The technique disadvantage is that it can cause distortion of samples since the EPS consists of approximately $95 \%$ water and the liquid loss led them to appear more like 
fibers surrounding the cells than like a gelatinous matrix (30). The advent of the transmission electron microscope, which uses specific polysaccharide stains such as ruthenium red, allowed researchers to identify the nature of the extracellular fibers in biofilms and lead to a better understand of their association with cells. Despite some limitations, the electron microscope is being employed until today for the examination and characterization of biofilms on medical devices and in human infections. Because of its excellent resolution properties, the electron microscope represents an important tool for biofilm investigation. Although at lower magnifications, another type of microscope used is the confocal laser scanning which permits in situ examination of biofilms without the limitations of the electron microscope, namely, the intact biofilm matrix state (30).

In a study regarding to microbial biofilm detection on venous catheters removed from ICU patients, Stort et al. (65) used scanning electron microscopy and reported that the extracellular biofilm matrix appears as an amorphous material on the catheter surface, similar to the observation of Donlan (29).

Confocal microscopy is the method of choice for the structural analysis of biofilms (52) since it permits the optical sectioning in hydrated state without destroying the samples, providing three-dimensional data of the structure. In addition, confocal microscopy permits the analysis of multiple-channel images and thus provides spatial information about the various biofilm functions. The noninvasive characteristics of the confocal microscope also favor the investigation of biofilms cultured on flow cells, which are small chambers whose top and bottom consist of glass lamellae and which can be coupled to a microscope for the observation of biofilms growing on the inner walls (61).

Contrast microscopy is recommended for the real-time monitoring of biofilms developing on a transparent surface. Epifluorescence microscopy is an excellent alternative for the quantification of surface-adhered cells. For the visualization of bacterial adhesion, fluorescent dyes such as acridine orange are used for direct staining of the cells, or fluorescent antibodies that bind to the cells (17).

Electron microscopy is more indicated for the evaluation of interactions that occur in the biofilm matrix. The samples are fixed with chemical agents, such as glutaraldehyde, paraformaldehyde and osmium, or are cryofixed, a process in which the sample is quickly frozen to prevent cell damage caused by the ice crystals (17). 
Non-visual methods used for the evaluation of bacterial adherence and biofilm formation are impedance and bioluminescence measurement. Impedance measuring is based on the principle that when metabolizing components are present in the culture medium, microorganisms transform large molecules into small ones that are electrically charged, an event leading to a change in the resistance or impedance of the medium. The change in conductivity can be measured and the number of microorganisms adhered to the surface is related to the conductivity obtained (62). The bioluminescence assay is based on the content of adenosine triphosphate (ATP), the universal energy currency in biological systems, whose generation in the bacterial cell is similar to that observed for all life forms. ATP is generated by the oxidation of nutrient molecules such as glucose, fatty and amino acids. The amount of ATP in a sample can be measured by the bioluminescence reaction between luciferin and the enzyme luciferase (39).

The most commonly used qualitative method for the analysis of biofilm production is the tube adherence method described by Christensen et al. (13). This method has been employed by several investigators with reliable results and has been shown to be efficient, presenting excellent sensitivity and adequate specificity, providing a consistent and adequate diagnosis in routine applications $(24,27,28,38,44,50)$. In a study comparing the reliability of three biofilm detection methods in S. aureus, a TCP assay, a tube test and Congo red agar, Knobloch et al. (49) reported good correlation between the tube test (13) and TCP assay for strongly biofilm-producing strains, whereas weak producers were not safely discriminated from non-producing strains. In contrast, screening on Congo red agar showed a low correlation with the tube test and TCP assay (15) and was therefore not recommend for the investigation of biofilm production by $S$. aureus. Similar results have been reported by Mathur et al. (56) who evaluated three different selection methods, including the tube adherence test, Congo red agar method and TCP assay, for the detection of biofilm formation in clinical staphylococcal isolates. The TCP assay was highly satisfactory in terms of biofilm-positive phenotype detection, with easy discrimination between strong, moderate or weak producers and non-producers. The tube adherence test presented high correlation with the TCP method, but weak producers were difficult to discriminate from biofilm-negative isolates. In contrast, the Congo red agar method did not presented a good correlation with either of the two other methods. The authors concluded that the TCP method was the most sensitive and accurate 
selection method showing good reproducibility for the detection of biofilm formation in Staphylococcus and had the advantage of being a quantitative method for the study of the adherence of Staphylococcus to medical devices.

The advances in DNA technology additionally offer the possibility of detecting genes encoding this polysaccharide. Arciola et al. (5), investigating the presence of the icaA and icaD genes in slime-producing staphylococcal strains from catheter-association infections, used PCR because they considered the method simple, fast, reliable and reported that it required minimal amounts of DNA for the detection of these genes in S. epidermidis and S. aureus strains. Lopes et al. (55) obtained excellent results with PCR, with the method permitting the differential detection of the ica locus between $S$. aureus and S. epidermidis.

\section{CONCLUSIONS}

Bacterial infections have been one of the main causes of implant failure, especially those caused by bacteria of normal flora which show an excellent performance in the colonization of prosthetic and other medical devices, rendering these organisms pathogenic to the host. This success in the colonization and development of infection has been related to the capacity of these microorganisms to produce slime, which also interferes with the treatment of infections, impairing the action of host immune cells and compromising antibiotic efficacy.

Studies on biofilms have shown that $S$. epidermidis is the most frequently isolated slime-producing CNS and is also the most common cause of nosocomial infections in patients with catheters, medical implants or other invasive devices. There is still a wide field of research on this subject; for example, what makes $S$. epidermidis a successful colonizer of the human skin and mucosal membranes; how does bacterial competition works; how bacterium-host interaction can be explained; and how saprophytic microorganisms become pathogenic? Regarding to slime production and the consequent biofilm formation, many aspects still need to be explored since divergences exist in the literature. Some studies suggest that CNS infections are mainly caused by adherent slime producers, whereas others do not confirm this finding. Therefore, further studies about the formation of biofilms by these microorganisms are necessary, as well as the improvement of detection methods and treatments to prevent their production. 


\section{REFERENCES}

1 ALCARAZ LE., SATORRES SE., LUCERO RM., CENTORBI ONP. Species identification, slime production and oxacillin susceptibility in coagulase-negative staphylococci isolated from nosocomial specimens. Braz. J. Microbiol., 2003, 34, 4551.

2 ALEXANDER W., RIMLAND D. Lack of correlation of slime production with pathogenicity in continuous ambulatory peritoneal dialysis peritonitis caused by coagulase negative staphylococci. Diagn. Microbiol. Infect. Dis., 1987, 8, 215-20.

3 AMMENDOLIA MG., DI ROSA R., MONTANARO L., ARCIOLA CR., BALDASSARRI L. Slime production and expression of the slime-associated antigen by staphylococcal clinical isolates. J. Clin. Microbiol., 1999, 37, 3235-8.

4 ARCíOLA CR., BALDASSARRI L., MONTANARO L. Presence of icaA and icaD genes and slime production in a collection of staphylococcal strains from catheterassociated infection. J. Clin. Microbiol., 2001, 39, 2151-6.

5 ARCIOLA CR., CAMPOCCIA D., GAMBERINI S., CERVELLATI M., DONATI E., MONTANARO L. Detection of slime production by means of an optimized Congo red agar plate test based on a colourimetric scale in Staphylococcus epidermidis clinical isolates genotyped for ica locus. Biomaterials, 2002, 23, 4233-9.

6 ARCIOLA CR., CAMPOCCIA D., GAMBERINI S., DONATI ME., BALDASSARI L., MONTANARO L. Occurrence of ica genes for slime synthesis in a collection of Staphylococcus epidermidis strains from orthopedic prosthesis infections. Acta Orthop. Scand., 2003, 74, 617-21.

7 BALDASSARI L., DONELLI G., GELOSIA A., SIMPSON AW., CHRISTENSEN GD. Expression of slime interferes with in vitro detection of host protein receptors of Staphylococcus epidermidis. Infect. Immun., 1997, 65, 1522-6.

8 BAYSTON R., PENNY SR. Excessive production of mucoid substance in staphylococcus SIIA: a possible factor in colonization of Holter shunts. Dev. Med. Child. Neurol. Suppl., 1972, 27, 25-8.

9 CAFISO V., BERTUCCIO T., CAMPANILE F., AMICOSANTE G., PERILLI MG., SELAN L., NICOLETTI G., STEFANI S. Presence of the ica operon in clinical isolates of Staphylococcus epidermidis and its role in biofilm production. Clin. Microbiol. Infect., 2004,10, 1081-8. 
10 CERCA N., MARTINS S., CERCA F., JEFFERSON K., PIER GB., OLIVEIRA R., AZEREDO J. Comparative assessment of antibiotic susceptibility of coagulasenegative staphylococci in biofilm versus planktonic culture as assessed by bacterial enumeration or rapid XTT colorimetry. J. Antimicrob. Chemother, 2005, 56, 331-6.

11 CHARACKLIS WG. Attached microbial growths, II: frictional resistance due to microbial slimes. Water Res., 1973, 7, 1249-58.

12 CHARACKLIS WG., MARSHALL KC. Biofilms: a basis for an interdisciplinary approach. In: CHARACKLIS WG., MARSHALL KC. Biofilms I. New York: John Wiley \& Sons, 1990. P. 3-15.

13 CHRISTENSEN GD., BADDOUR LM., SIMPSON WA. Phenotypic variation of Staphylococcus epidermidis slime production in vitro and in vivo. Infect. Immun., 1987, 55, 2870-7.

14 CHRISTENSEN GD., BISNO AL., SIMPSON WA., BEACHEY EH. Adherence of slime-producing strains of Staphylococcus epidermidis to smooth surfaces. Infect. Immun., 1982, 37, 318-26.

15 CHRISTENSEN GD., PARISI JT., BISNO AL., SIMPSOM WA., BEACHEY EH. Characterization of clinically significant strains of coagulase-negative staphylococci. J. Clin. Microbiol., 1983, 18, 258-69.

16 CONLON KM., HUMPHREYS H., O'GARA JP. icaR encodes a transcriptional repressor involved in environmental regulation of ica operon expression and biofilm formation in Staphylococcus epidermidis. J. Bacteriol., 2002, 184, 4400-8.

17 COSTA ETR. Desenvolvimento de metodologia para detecção da adesão microbiana em superfície de aço inoxidável. Seropédica: Universidade Federal do Rio de Janeiro, 1999. 81p. [Masters dissertation]

18 COSTA SF., MICELI MH., ANAISSIE EJ. Mucosa or skin as source of coagulasenegative stphylococcal bacteremia? Lancet Infect. Dis., 2004, 4, 278-86.

19 COSTERTON JW., GEESEY GG., CHENG KJ. How bacteria stick. Sci. Am., 1978, 238, 86-95.

20 COSTERTON JW., LASHEN ES. Influence of biofilm on efficacy of biocides on corrosion-causing bacteria. Mater. Perform., 1984, 23, 13-7.

21 COSTERTON JW., LEWANDOWSKI Z., CALDWELL DE, KORBER DR., LAPPIN-SCOTT HM. Microbial biofilms. Annu. Rev. Microbiol., 1995, 49, 711-45. 
22 COSTERTON W., VEEH R., SHIRTLIFF M., PASMORE M., POST C., EHRLICH G. The application of biofilm science to the study and control of chronic bacterial infections. J. Clin. Invest., 2003, 112, 1466-77.

23 CRAMTON SE., ULRICH M., GOTZ F., DORING G. Anaerobic conditions induce expression of polysaccharide intercellular adhesion in Staphylococcus aureus and Staphylococcus epidermidis. Infect. Immun., 2001, 69, 4079-85.

24 CUNHA ML., CARAMORI JCT., FIORAVANTE AM., BATALHA JEN., MONTELLI AC., BARRETTI P. Significance of slime as virulence factor in coagulase-negative Staphylococcus peritonitis in CAPD. Perit. Dial. Int., 2004, 24, 191-3.

25 CUNHA ML., LOPES CA., RUGOLO LM., CHALITTA LV. Clinical significance of coagulase-negative staphylococci isolated from neonates. J. Pediatr., 2002, 78, 27988.

26 CUNHA ML., RUGOLO LM., LOPES CA. Study of virulence factors in coagulasenegative staphylococci isolated from newborns. Mem. Inst. Oswaldo Cruz, 2006, 101, 661-8.

27 DAVEY ME., O'TOOLE GA. Microbial biofilms: from ecology to molecular genetics. Microbiol. Mol. Biol. Rev., 2000, 64, 847-67.

28 DIAZ-MITOMA F., HARDING GK., HOBAN DJ., ROBERTS RS., LOW DE. Clinical significance of a test for slime production in ventriculoperitoneal shunt infections caused by coagulase-negative staphylococci. J. Infect. Dis., 1987, 156, 555-60.

29 DONLAN RM. Biofilms: microbial life on surfaces. Emerg. Infect. Dis., 2002, 8, 881-90.

30 DONLAN RM., COSTERTON JW. Biofilms: survival mechanisms of clinically relevant microorganisms. Clin. Microbiol. Rev., 2002, 15, 167-93.

31 DUNNE JR WM., NELSON DB., CHUSID MJ. Epidemiology markers of pediatric infections caused by coagulase-negative staphylococci. Pediatr. Infect. Dis. J., 1987, 6, 1031-5.

32 FITZGERALD SF., FITZPATRICK F., DILANE T., SMITH EG., HUMPHREYS H., O'GARA JP. Genomic diversity of Staphylococcus epidermidis isolates from the intensive care unit. Clin. Microbiol. Infect., 2004, 10, 1081-8. 
33 FLEURETTE J., BES M., BRUN Y., FRENEY J., FOREY F., COULET M., REVERDY ME., ETIENNE J. Clinical isolates of Staphylococcus lugdunensis and S. schleiferi: bacteriological characteristics and susceptibility to antimicrobial agent. Res. Microbiol., 1989, 140, 107-18.

34 FREEMAN DJ., FALKINER FR., KEANE CT. New method for detecting slime production by coagulase-negative staphylococci. J. Clin. Pathol., 1989, 42, 872-4.

35 GELOSIA A., BALDASSARRI L., DEIGHTON M., VAN NGUYEN T. Phenotypic and genotypic markers of Staphylococcus epidermidis virulence. Clin. Microbiol. Infect., 2001, 7, 193-9.

36 GERKE C., KRAFT A., SUSSMUTH R., SCHWEITZER O., GOTZ F. Characterization of the $\mathrm{N}$-acetylglucosaminyltransferase activity involved in the biossynthesis of the Staphylococcus epidermidis polysaccharide intercellular adhesion. J. Biol. Chem., 1998, 273, 18586-93.

37 GHIGO JM. Natural conjugative plasmids induce bacterial biofilm development. Nature, 2001, 412, 442-5.

38 GONGORA-RUBIO F., PIGNATARI ACC., COSTA LMD. Significância clínica, epidemiologia e microbiologia das bacteremias por estafilococos coagulasenegativos em Hospital de Ensino. Rev. Assoc. Med. Bras., 1997, 43, 9-14.

39 GOTZ F. Staphylococcus and biofilms. Mol. Microbiol., 2002, 43, 1367-78.

40 HALL RT., HALL SL., BARNES WG., IZUEGBU J., ROGOLSKY M., ZORBOS I. Characteristics of coagulase-negative staphylococci from infants with bacteremia. Pediatr. Infect. Dis. J., 1987, 6, 377-83.

41 HEILMANN C., SCHWEITZER O., GERKE C., VANITTANAKOM N., MACK D., GOTZ F. Molecular basis of intercellular adhesion in the biofilm-forming Staphylococcus epidermidis. Mol. Microbiol., 1996, 20, 1083-91.

42 HEUKELEKIAN H., HELLER A. Relation between food concentration and surface for bacterial growth. J. Bacteriol., 1940, 40, 547-58.

43 HUSSAIN M., HASTINGS JG., WHITE PJ. Isolation and composition of the extracellular slime made by coagulase-negative staphylococci in a chemically defined medium. J. Infect. Dis., 1991, 163, 534-41.

44 ISHAK MA., GROSCHEL DH., MANDELL GL., WENZEL RP. Association of slime with pathogenicity of coagulase-negative staphylococci causing nosocomial septicemia. J. Clin. Microbiol., 1985, 22, 1025-9. 
45 JAMES GA., BEAUDETTE L., COSTERTON JW. Interspecies bacterial interactions in biofilms. J. Ind. Microbiol., 1995, 15, 257-62.

46 JONES HC., ROTH IL., SAUNDERS WM. Electron microscopic of a slime layer. J. Bacteriol., 1969, 99, 316-25.

47 JONES JW., SCOTT RJ., MORGAN J., PETER JV. A study of coagulasenegative staphylococci with reference to slime production, adherence, antibiotic resistance patterns and clinical significance. J. Hosp. Infect., 1992, 22, 217-27.

48 KNOBLOCH JK., BARTSCHT K., SABOTTKE A., ROHDE H., FEUCHT HH., MACK D. Biofilm formation by Staphylococcus epidermidis depends on functional RsbU, an activator of the sigB operon: differential activation mechanisms due to ethanol and salt stress. J. Bacteriol., 2001, 183, 2624-33.

49 KNOBLOCH JK., HORSTKOTTE MA., RODHE H., MACK D. Evaluation of different detection methods of biofilm formation in Staphylococcus aureus. Med. Microbiol. Immunol., 2002, 191, 101-6.

50 KOTILAINEN P. Association of coagulase-negative staphylococcal slime production and adherence with the development and outcome of adult septicemias. J. Clin. Microbiol., 1990, 28, 2779-85.

51 LARKUM AWD., KOCH EMW., KUHL M. Diffusive boundary layers and photosynthesis of the epilithic algal community of coral reefs. Mar. Biol., 2003, 142, 1073-82.

52 LAWRENCE JR., NEU TR. Confocal laser scanning microscopy for analysis of microbial biofilms. Methods Enzymol., 1999, 310, 131-44.

53 LERICHE V., SIBILLE P., CARPENTIER B. Use of an enzyme-linked lectinsorbent assay to monitor the shift in polysaccharide composition in bacterial biofilms. Appl. Environ. Microbiol., 2000, 66, 1851-6.

54 LI H., WANG J., WEN Y., VUONG C., OTTO M., GAO Q. Conversion of Staphylococcus epidermis strains from commensal to invasive by expression of the ica locus encoding production of biofilm exopolysaccharide. Infect. Immun., 2005, 73, 3188-91.

55 MARTIN-LOPEZ JV., DIEZ-GIL O., MORALES M., BATISTA N., VILLAR J., CLAVERIE-MARTIN, F., MENDEZ-ALVAREZ S. Simultaneous PCR detection of ica cluster and methicillin and mupirocin resistance genes in catheter-isolated Staphylococcus. Int. Microbiol., 2004, 7, 63-6. 
56 MATHUR T., SINGHAL S., KHAN S., UPADHYAY DJ., FATIMA T., RATTAN A. Detection of biofilm formation among the clinical isolates of staphylococci: an evaluation of three different screening methods. Indian J. Med. Microbiol., 2006, 24, 25-9.

57 MORALES M., MENDEZ-ALVAREZ S., MARTIN-LOPES JV., MARRERO C., FREYTES CO. Biofilm: the microbial "bunker" for intravascular catheter-related infection. Support Care Cancer, 2004, 12, 701-7.

58 MURGA R., FORSTER TS., BROWN E., PRUCKLER JM., FIELDS BS., DONLAN RM. Role of biofilms in the survival of Legionella pneumophila in a model potablewater system. Microbiology, 2001, 147, 3121-6.

59 NILSDOTTER-AUGUSTINSSON A., CLAESSON C., LINDGREN PE., LUNDQVIST-GUSTAFSSON H., OHMAN L. Adherence of Staphylococcus epidermidis to extracellular matrix proteins and effects of fibrinogen-bound bacteria on oxidase activity and apoptosis in neutrophils. APMIS, 2005, 113, 361-73.

60 O'GARA JP., HUMPHREYS H. Staphylococcus epidermidis biofilms: importance and implications. J. Med. Microbiol., 2001, 50, 582-7.

61 PALMER JR RJ. Microscopy flowcells: perfusion chambers for real-time study of biofilms. Methods Enzymol., 1999, 310, 160-6.

62 RULE P. Measurement of microbial activity by impedance. In: TORTORELLO ML., GENDEL SM. Food microbiological analysis: new technologies. New York: Marcel Dekker, 1997. P. 315-43.

63 STOODLEY P., BOYLE JD., DODDS I., LAPPIN-SCOTT HM. Consensus model of biofilm structure. In: WIMPENNY JWT., HANDLEY PS., GILBERT P., LAPPINSCOTT HM., JONES M. (Eds.) Biofilms: community interactions and control. UK: Bioline, Cardiff, 1997. P. 1-9.

64 STOODLEY P., COSTERTON JW., HALL-STOODLEY L. Bacterial biofilms: from the natural environment to infectious diseases. Nat. Rev. Microbiol., 2004, 2, 95-108. 65 STORT A., PIZZOLITTO CA., PIZZOLITTO LE. Detection of mixed microbial biofilms on central venous catheters removed from intensive care unit patients. Braz. J. Microbiol., 2005, 36, 275-80.

66 SUTHERLAND IW. Biofilm exopolysaccharides: a strong and sticky framework. Microbiol., 2001, 147, 3-9.

67 TOLKER-NIELSEN T., MOLIN S. Spatial organization of microbial biofilm communities. Microbiol. Ecol., 2000, 40, 75-84. 
A. Oliveira and M. L. R. S. Cunha BACTERIAL BIOFILMS WITH EMPHASIS ON COAGULASE-NEGATIVE STAPHYLOCOCCI. J. Venom. Anim. Toxins incl. Trop. Dis., 2008, 14, 4, p. 596

68 VUONG C., OTTO M. Staphylococcus epidermidis infections. Microbes Infect., 2002, 4, 481-9.

69 ZOBELL CE. The effect of solid surfaces on bacterial activity. J. Bacteriol., 1943, 46, 39-56. 